\title{
ANTIMICROBIAL ACTIVITY OF METHANOL EXTRACTS OF FOUR PARMELIACEAE LICHEN SPECIES ${ }^{\dagger}$
}

\author{
UDC $582.29: 615.28$
}

\author{
Igor Stojanović ${ }^{1 *}$, Niko Radulović ${ }^{2}$, Vladimir Cvetković ${ }^{3}$, \\ Tatjana Mitrović ${ }^{3}$, Slaviša Stamenković ${ }^{3}$ \\ ${ }^{1}$ Department of Pharmacy, Faculty of Medicine, University of Niš, \\ bul. Z. Djindjića 81,18000 Niš, Serbia \\ ${ }^{2}$ Department of Chemistry, Faculty of Science and Mathematics, \\ University of Niš, Višegradska 33, 18000 Niš, Serbia \\ ${ }^{3}$ Department of Biology and Ecology, Faculty of Science and Mathematics, \\ University of Niš, Višegradska 33, 18000 Niš, Serbia
}

\begin{abstract}
Antimicrobial activity of methanol extracts of four Parmeliaceae lichens (Hypogymnia physodes (L.) Nyl., Evernia prunastri (L.) Ach., Flavoparmelia caperata (L.) Hale and Parmelia sulcata Taylor) against a panel of microbial strains (11 Gram-positive (Enterococus sp., Bacillus subtillis, Sarcina lutea, Micrococus luteus, Staphylococcus aureus, Clostridium sporogenes) and Gram-negative bacteria (Escherichia coli, Proteus vulgaris, Salmonela enteritidis, Pseudomonas aeruginosa, Klebsiella pneumoniae), the filamentous fungus A. niger and the yeast $C$. albicans) was assayed using a disk diffusion method (1 mg of the extract per disc; extracts were dissolved in methanol, $25 \mathrm{mg} / \mathrm{mL}$ ). All tested extracts showed moderate antimicrobial activity. Multivariate statistical treatment (agglomerative hierarchical clustering analysis, AHC) of the obtained results allowed grouping of the samples according to their antimicrobial potential against different strains: antimicrobial profile of $H$. physodes and E. prunastri extracts were comparable; the similar is true for F. caperata and P. sulcata samples. In addition, based on the similarities/ dissimilarities in their susceptibility toward the tested extracts, two groups of microorganisms could be distinguished: Group I - P. vulgaris, K. pneumoniae (Gram-negative bacteria), A. niger and C. albicans; Group II - E. coli, S. enteritidis, P. aeruginosa (Gram-negative bacteria) and all of the assayed Gram-positive strains.
\end{abstract}

Key words: Hypogymnia physodes (L.) Nyl., Evernia prunastri (L.) Ach., Flavoparmelia caperata (L.) Hale, Parmelia sulcata Taylor, methanol extract, antimicrobial activity

Received May $14^{\text {th }}, 2013$; revised July $18^{\text {th }}, 2013$; accepted July $22^{\text {th }}, 2013$.

${ }^{\dagger}$ Acknowledgement: This research was supported by Ministry of Education, Science and Technological Development of Republic Serbia (Project 172044). A part of these results was presented at $10^{\text {th }}$ Symposium on the Flora of Southeastern Serbia and Neighbouring regions, Vlasina, June 2010, Book of Abstracts, 98

*Contacts of Corresponding author: igor.pfc@hotmail.com. 


\section{INTRODUCTION}

Lichens (symbiotic association between fungi and algae and/or cyanobacteria) are an excellent source of a great number of different secondary metabolites with unique chemical structures. Up to now, more than 1000 compounds exclusive to these organisms were found [1]. Many of these are biologically active. They are antibacterial, antiviral, antiinflammatory, analgesic, antipyretic, antiproliferative and cytotoxic agents [2-5]. However, therapeutic potential of lichens has not been fully exploited, probably because of their slow growth in nature and difficulties to propagate them in culture [6]. Although numerous papers have been published on antimicrobial activity of lichen extracts/pure constituents [7-19], their possible effect on several widespread human pathogens has not been evaluated so far.

Bearing in mind the importance of the search for new natural antimicrobial agents-the contemporary development of microbial resistance to common antibiotics is a very serious problem-the aim of the present study was to evaluate in vitro antimicrobial activities of methanol extracts of four Parmeliaceae lichens: Hypogymnia physodes (L.) Nyl., Evernia prunastri (L.) Ach., Flavoparmelia caperata (L.) Hale and Parmelia sulcata Taylor against 11 Gram-positive (Enterococus sp., Bacillus subtillis, Sarcina lutea, Micrococus luteus, Staphylococcus aureus, Clostridium sporogenes) and Gram-negative bacteria (Escherichia coli, Proteus vulgaris, Salmonela enteritidis, Pseudomonas aeruginosa, Klebsiella pneumoniae), the filamentous fungus Aspergillus niger and the yeast Candida albicans. These common microorganisms were chosen as they are known to cause serious health disorders in humans (Table 1). To the best of our knowledge this is the first study of antimicrobial properties of the abovementioned extracts toward Clostridium sporogenes, Micrococcus luteus, Sarcina lutea and Aspergillus niger.

A broth dilution susceptibility method was the method of choice in the majority of studies focused on antimicrobial properties of lichen extracts/metabolites $[8,10,11,14$ 18]. Nevertheless, in a few studies [9, 12, 13], a disk diffusion (DD) method was also successfully applied. Its relatively simple and non-time consuming methodology is an excellent choice for screening studies that include a large number of samples. Ranković et al. used this method to study the antimicrobial potential of methanolic extracts of $F$. caperata, H. physodes [12] and P. sulcata [13]. Similarly, Halama and Haluwin (2004) [9] showed (by a DD method) that acetone extracts of E. prunastri, H. physodes and Cladonia portentosa (Dufour) Coem. were strong inhibitors of growth of several plant pathogenic fungi. For these reasons, in this study we also applied a disk diffusion susceptibility method.

In addition, in order to provide a better insight into the similarities/dissimilarities of antimicrobial properties of the studied extracts, and in susceptibility of the tested microbial strains, we have subjected the obtained activity data to multivariate statistical analysis (agglomerative hierarchical cluster analysis, AHC). 
Table 1 Overview of infectious diseases caused by microorganisms studied in this work [20]

\begin{tabular}{|c|c|}
\hline $\begin{array}{l}\text { Microorganism } \\
\text { (designation/type }^{\mathrm{a}} \text { ) }\end{array}$ & Health disorder \\
\hline P. aeruginosa (L1/-) & $\begin{array}{l}\text { Pneumonias in cystic fibrosis or in patients on respiratory equipment, } \\
\text { infections of burn wounds, postoperative wound infections, chronic } \\
\text { pyelonephritis, endocarditis in drug addicts, sepsis, malignant otitis } \\
\text { externa, and nosocomial infections }\end{array}$ \\
\hline S. enteritidis (L7/-) & Gastroenteritis (diarrhea) and profuse watery diarrhea \\
\hline $\begin{array}{l}\text { P. vulgaris } \\
(\text { L10/-) }\end{array}$ & $\begin{array}{l}\text { Sepsis, wound infections, infections of the urinary tract and respiratory } \\
\text { tract nosocomial infections }\end{array}$ \\
\hline $\begin{array}{l}\text { S. aureus } \\
(\text { L11/-) }\end{array}$ & $\begin{array}{l}\text { Invasive infections: furuncles, carbuncles, wound infections, sinusitis, otitis } \\
\text { media, mastitis puerperalis, postoperative or posttraumatic } \\
\text { ostitis/osteomyelitis, endocarditis following heart surgery (especially } \\
\text { valvereplacement), postinfluenza pneumonia, and sepsis in } \\
\text { immunocompromised patients, derrmatitis exfoliativa (staphylococcal } \\
\text { scalded skin syndrome, Ritter disease), pemphigus neonatorum, and } \\
\text { bullous impetigo }\end{array}$ \\
\hline $\begin{array}{l}\text { E. coli } \\
\text { (L13/-) }\end{array}$ & $\begin{array}{l}\text { Urethritis, cystitis, urethrocystitis, cystopyelitis, pyelonephritis sepsis, } \\
\text { wound infections, infections of the gallbladder and bile ducts, appendicitis, } \\
\text { peritonitis, meningitis in premature infants, neonates and elderly patients }\end{array}$ \\
\hline $\begin{array}{l}\text { K. pneumoniae } \\
\text { (L2/+) }\end{array}$ & Friedlander's pneumonia \\
\hline $\begin{array}{l}\text { Enterococcus sp. } \\
\text { (L5/+) }\end{array}$ & Nosocomial infections \\
\hline $\begin{array}{l}\text { B. subtilis } \\
\text { (L6/+) }\end{array}$ & Food poisoning \\
\hline $\begin{array}{l}\text { S. lutea } \\
\text { (L8/+) }\end{array}$ & Skin infections in immunocompromised patients \\
\hline $\begin{array}{l}\text { M. luteus } \\
\text { (L9/+) }\end{array}$ & Skin infections in immunocompromised patients \\
\hline $\begin{array}{l}\text { Cl. sporogenes } \\
(\mathrm{L} 12 /+)\end{array}$ & Gangrenous cellulitis \\
\hline $\begin{array}{l}\text { A. niger } \\
(\mathrm{L} 3 / \mathrm{f})\end{array}$ & $\begin{array}{l}\text { Opportunistic mycoses: aspergilloses of the respiratory tract, } \\
\text { endophthalmitis; aspergillosis of CNS, and septic aspergillosis }\end{array}$ \\
\hline $\begin{array}{l}\text { C. albicans } \\
\text { (L4/y) }\end{array}$ & $\begin{array}{l}\text { Infection of lower respiratory tract, pulmonary abscess, necrotizing } \\
\text { pneumonia, vulvovaginitis, peritonitis following peritoneal dialysis, } \\
\text { meningitis, cerebral abscess, epidural abscess, subdural empyema, } \\
\text { myocarditis/pericarditis, conjunctivitis/scleritis, keratitis, endophthalmitis, } \\
\text { otitis externa, and dermatomycoses }\end{array}$ \\
\hline
\end{tabular}




\section{MATERIALS AND METHODS}

\subsection{Lichen material}

Lichens species, H. physodes, (monk's-hood lichen, hooded tube lichen, puffed lichen), E. prunastri (oakmoss [21]), F. caperata (syn. Parmelia caperata (L.) Ach.; greenshield lichen) and $P$. sulcata (shield lichen), growing on Prunus domestica L., were collected on the Bojanine vode locality near Niš at an altitude of $860 \mathrm{~m}$ above sea level, in April 2009. The lichen material was air-dried for 10 days and stored at ambient temperature $\left(25 \pm 2{ }^{\circ} \mathrm{C}\right)$ without exposure to direct sunlight. Taxonomical identification was based on the key as described in Murati (1992) [22]. Voucher specimens were deposited in the Herbarium Department of Biology and Ecology, Faculty of Sciences and Mathematics, University of Niš of under the acquisition numbers: 17 (H. physodes), 18 (E. prunastri), 19 (F. caperata), and 20 (P. sulcata).

Table 2 Antimicrobial activity of the extracts of four Parmeliaceae species

\begin{tabular}{|c|c|c|c|c|c|c|}
\hline \multirow[b]{2}{*}{$\begin{array}{l}\text { Microorganism } \\
\left(\text { designation/type }^{b}\right)\end{array}$} & \multicolumn{6}{|c|}{ Growth inhibition zones $(\mathrm{mm})^{\mathrm{a}}$} \\
\hline & $\begin{array}{c}P . \\
\text { sulcata }^{\mathrm{c}} \\
\text { (PS) }\end{array}$ & $\begin{array}{c}E . \\
\text { prunastri } \\
\text { (EP) }\end{array}$ & $\begin{array}{c}F . \\
\text { caperata } \\
\text { (FC) }\end{array}$ & $\begin{array}{c}H . \\
\text { physodes } \\
\text { (HP) }\end{array}$ & Tetracycline & Nystatin \\
\hline P. aeruginosa (L1/-) & $17.7 \pm 0.6^{\mathrm{d}}$ & $23.0 \pm 1.0$ & $18.3 \pm 0.6$ & $21.7 \pm 1.2$ & $26.3 \pm 0.6$ & n.t. $^{\mathrm{e}}$ \\
\hline S. enteritidis (L7/-) & $17.0 \pm 1.0$ & $22.7 \pm 0.6$ & $18.7 \pm 0.6$ & $22.3 \pm 0.6$ & $26.0 \pm 2.0$ & n.t. \\
\hline P. vulgaris (L10/-) & $15.7 \pm 1.2$ & $22.33 \pm 1.5$ & $19.7 \pm 0.6$ & $19.0 \pm 1.0$ & $26.0 \pm 1.0$ & n.t. \\
\hline S. aureus (L11/-) & $15.7 \pm 0.6$ & $21.3 \pm 0.6$ & $16.3 \pm 0.6$ & $20.7 \pm 0.6$ & $25.7 \pm 0.6$ & n.t. \\
\hline E. coli $(\mathrm{L} 13 /-)$ & $16.3 \pm 0.6$ & $23.0 \pm 1.0$ & $19.7 \pm 0.6$ & $21.7 \pm 1.2$ & $27.3 \pm 0.6$ & n.t. \\
\hline K. pneumoniae (L2/+) & $19.0 \pm 1.0$ & $18.3 \pm 1.5$ & $21.7 \pm 0.6$ & $19.3 \pm 0.58$ & $23.3 \pm 0.6$ & n.t. \\
\hline Enterococcus sp. (L5/+) & $16.3 \pm 1.5$ & $22.7 \pm 0.6$ & $17.0 \pm 1.0$ & $21.3 \pm 1.5$ & $28.0 \pm 1.0$ & n.t. \\
\hline B. subtilis (L6/+) & $15.7 \pm 0.6$ & $22.7 \pm 0.6$ & $18.0 \pm 2.0$ & $20.0 \pm 2.0$ & $27.0 \pm 1.0$ & n.t. \\
\hline S. lutea $(\mathrm{L} 8 /+)$ & $16.7 \pm 0.6$ & $22.3 \pm 1.5$ & $17.7 \pm 0.6$ & $21.3 \pm 1.5$ & $27.7 \pm 11.2$ & n.t. \\
\hline M. luteus $(\mathrm{L} 9 /+)$ & $16.7 \pm 1.2$ & $24.7 \pm 0.6$ & $17.7 \pm 1.2$ & $22.7 \pm 2.1$ & $31.3 \pm 1.5$ & n.t. \\
\hline Cl. sporogenes $(\mathrm{L} 12 /+)$ & $15.7 \pm 0.6$ & $25.7 \pm 1.5$ & $17.7 \pm 1.2$ & $21.3 \pm 0.6$ & $27.3 \pm 0.6$ & n.t. \\
\hline A. niger (L3/f) & $16.3 \pm 0.6$ & $20.3 \pm 0.6$ & $22.3 \pm 1.5$ & $19.7 \pm 1.2$ & n.t. & $18.3 \pm 0.6$ \\
\hline C. albicans (L4/y) & $15.3 \pm 1.5$ & $21.0 \pm 1.0$ & $20.7 \pm 2.1$ & $17.3 \pm 0.6$ & n.t. & $19.0 \pm 1.0$ \\
\hline
\end{tabular}

${ }^{\mathrm{a}}$ Including disk diameter $(12.7 \mathrm{~mm}) ;{ }^{\mathrm{b}}$ Gram-positive (+), Gram-negative (-), fungi (f) or yeast (y); ${ }^{\mathrm{c}} 1 \mathrm{mg}$ of sample per disk; ${ }^{\mathrm{d}}$ Mean value of 3 experiments \pm standard deviation (SD); ${ }^{\mathrm{e}}$ n.t. - not tested.

\subsection{Extraction}

Air-dried lichen material (10 g) was powdered, immersed in methanol $(250 \mathrm{~mL})$ and left at room temperature for $24 \mathrm{~h}$. After that, the obtained extracts were filtered and the solvent was evaporated in vacuo at $40{ }^{\circ} \mathrm{C}$. The yields of the obtained dry extracts of $H$. physodes, E. prunastri, F. caperata, P. sulcata were $14.4 \%, 11.5 \%, 12.0 \%, 11.0 \%$, respectively. For antimicrobial assays, the dry extracts were dissolved in methanol to a final the concentrations of $25 \mathrm{mg} / \mathrm{mL}$. 


\subsection{Antimicrobial activity}

The in vitro antimicrobial activity of the extracts against a panel of laboratory control strains belonging to the American Type Culture Collections, Maryland, USA was assayed. The following Gram-positive bacteria were used: Bacillus subtilis (ATCC 6633), Clostridium sporogenes (ATCC 19404), Enterococcus sp. (ATCC 25212), Micrococcus luteus (ATCC 10240), Sarcina lutea (ATCC 9341) and Staphylococcus aureus (ATCC 6538). Gram-negative bacteria utilized in the assays were: Klebsiella pneumoniae (ATCC 10031), Proteus vulgaris (ATCC 8427), Escherichia coli (ATCC 25922), Pseudomonas aeruginosa (ATCC 27857), and Salmonella enteritidis (ATCC 13076). The antifungal activity was tested against Aspergillus niger (ATCC 16404) and Candida albicans (ATCC 10231).

A disk diffusion method, according to the NCCLS [23], was employed for the determination of antimicrobial activity of the extracts. The following nutritive media were used: Antibiotic Medium 1 (Difco Laboratories, Detroit, MI USA) for Grampositive and Gram-negative bacteria; Tripton soy agar (TSA-Torlak, Belgrade) for $C$. albicans and A. niger. All nutritive media were prepared according to the instructions of the manufacturer; agar plates were prepared in $90 \mathrm{~mm} \varnothing$ Petri dishes with $22 \mathrm{~mL}$ of agar, giving a final depth of $4 \mathrm{~mm}$. One-hundred microlitres of a suspension of the tested microorganism $\left(10^{8}\right.$ cells per $\left.\mathrm{mL}\right)$ were spread on the solid media plates. Sterile filter paper disks ("Antibiotica Test Blattchen", Schleicher and Schuell, Dassel, Germany, $12.7 \mathrm{~mm}$ in diameter) were impregnated with $40 \mu \mathrm{L}$ of the samples solutions $(25 \mathrm{mg} / \mathrm{mL})$ in methanol (all solutions were filter-sterilized using a $0.45 \mu \mathrm{m}$ membrane filter), i.e. 1 mg per disk, and placed on inoculated plates. These plates, after standing at $4{ }^{\circ} \mathrm{C}$ for $2 \mathrm{~h}$, were incubated at $37{ }^{\circ} \mathrm{C}$ for $24 \mathrm{~h}$ for bacteria and at $30{ }^{\circ} \mathrm{C}$ for $48 \mathrm{~h}$ for fungi. Standard disks of tetracycline and nystatin (origin-Institute of Immunology and Virology "Torlak", $30 \mu \mathrm{g}$ of the active component, diameter $6 \mathrm{~mm}$ ) were used individually as positive controls, while the disks imbued with $40 \mu \mathrm{L}$ of pure methanol were used as a negative control.

The diameters of the inhibition zones were measured in millimeters using a "FisherLilly Antibiotic Zone Reader" (Fisher Scientific Co., USA). Each test was performed in triplicate. The obtained results are summarized in Table 2. The data were expressed as the means \pm standard deviation (SD). Mean differences were determined by Student's $t$-test. Values of $p<0.05$ were considered statistically significant.

\subsection{Agglomerative hierarchical clustering (AHC)}

AHC analysis was performed using an Excel program plug-in XLSTAT version 7.5.2., using Euclidean distance dissimilarity and aggregation criterion-Ward's method.

\section{RESULTS AND DISCUSSION}

The results of the antimicrobial assays are given in Table 2. The studied extracts inhibited the growth of all tested microorganisms; however, their antimicrobial potential was significantly lower than that of the applied positive control: for example, $30 \mu \mathrm{g}$ of tetracycline or nystatin per disc caused comparable inhibition of microbial growth as did $1 \mathrm{mg}$ of some of the extracts. Methanol (the negative control) had no inhibitory effect 
(the activity of the screened samples was statistically significant from that of negative control at the given confidence level $(\mathrm{p}<0.05))$. Thus, the antimicrobial potential of the herein studied lichen extracts against the tested microbial strains might be taken as only a moderate one (width of the inhibition zone without diameter disk ranged from 5 to $10 \mathrm{~mm})[24]$.

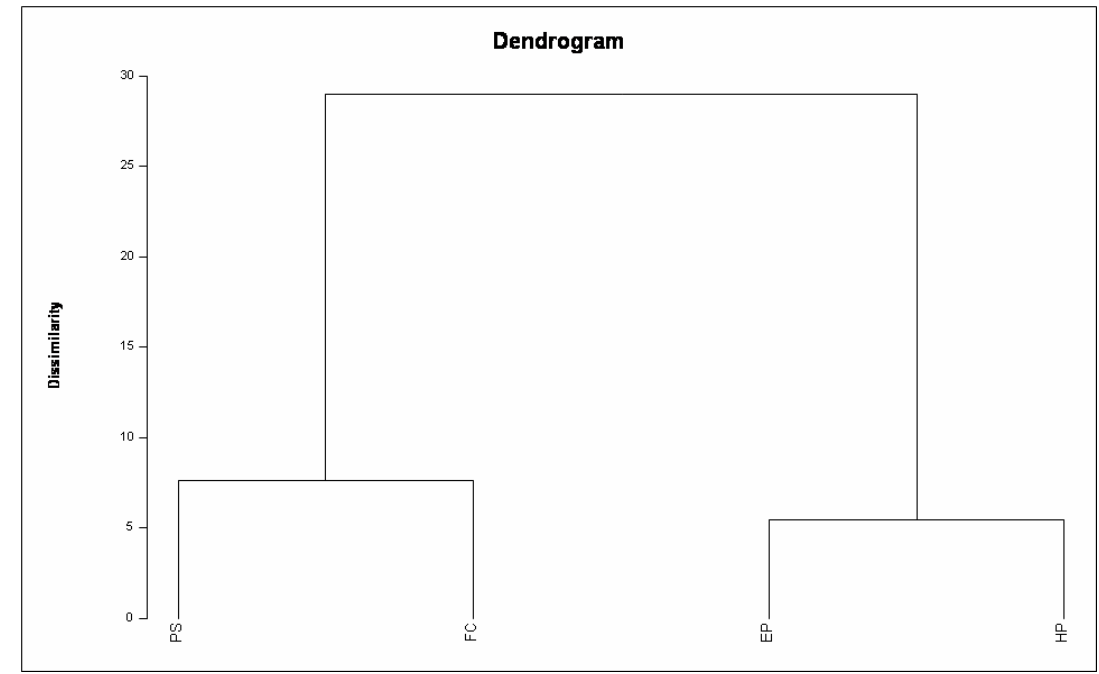

Fig. 1 Dendrogram (AHC analysis) representing antimicrobial activity (variable diameters of growth inhibition zones) dissimilarity relationships of the studied samples (HP-H. physodes, EP-E. prunastri, FC-F. caperata, PS-P. sulcata; observations) obtained by Euclidian distance dissimilarity (dissimilarity within the interval $[0,30])$, using aggregation criterion-Ward's method When mutually comparing the herein studied extracts, it is obvious from Table 2 that they display a relatively wide range of activities (diameters of inhibition zones, $\mathrm{mm}$ ): from $15 \mathrm{~mm}$ (activity of $P$. sulcata extract toward C. albicans and $S$. aureus) to $26 \mathrm{~mm}$ (activity of E. prunastri extract against $C l$. sporogenes).

A similar methodology (another DD method) was previously used to study the antimicrobial potential of $P$. sulcata, $F$. caperata, $H$. physodes and E. prunastri $[12,13]$. However, it is not possible to compare the current and previous results (absolute values of the diameters of inhibition zones) directly, as the diameters of the utilized discs were different (7 vs. $12.7 \mathrm{~mm}$ ). Nevertheless, the activities within the group of Gram-positive bacteria (those strains used both in this and previous studies [12, 13] were taken into account) followed the same trend. The opposite is true for Gram-negative bacteria (the reason for this might be sought in the fact that the same species, but not the same strains, were tested in these assays). Thus, even though lichen extracts were prepared in a different manner (Soxhlet versus room temperature extraction), one might conclude that the herein obtained results are in accordance with the previously published data. 


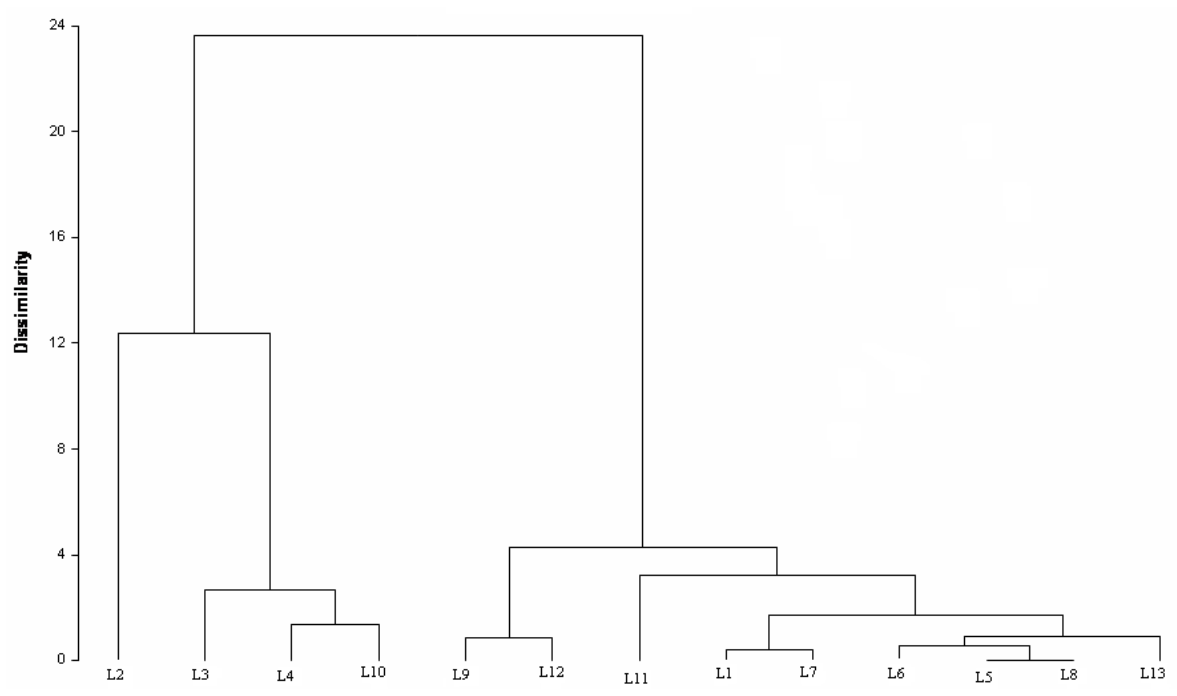

Fig. 2 Dendrogram (AHC analysis) representing antimicrobial activity (diameters of growth inhibition zones; variables) dissimilarity relationships of the susceptibilities of tested microorganisms (observations; L1-L13 (designations of the samples are defined in Tables 2 and 3)) obtained by Euclidian distance dissimilarity (dissimilarity within the interval [0, 24]), using aggregation criterion-Ward's method

In order to provide a better insight into the similarities/dissimilarities of the antimicrobial properties of the studied extracts, we have subjected the obtained activity data to multivariate statistical AHC analysis (diameters of inhibition zones were used as variables; extracts of the studied lichen species served as observations). The resulting dendrogram is given in Figure 1. According to AHC, the extract samples were divided into 2 groups. Members of the first group, H. physodes (HP) and E. prunastri extracts (EP), manifested stronger activity towards the majority of the tested microorganisms (diameter of inhibition zones ranged from 17 to $26 \mathrm{~mm}$ ) in comparison to the samples of the second group ( $F$. caperata (FC) and $P$. sulcata extracts (PS); diameter of inhibition zones ranged from 15 to $22 \mathrm{~mm}$ ). The only exception is the strong antifungal activity of the FC sample. The mentioned AHC grouping of the extract samples is in general agreement with the data on the (major) secondary metabolites of the studied lichens (Table 3; data from the literature).

Table 3 The main extract constituents of $P$. sulcata, $F$. caperata, E. prunastri and H. physodes (data from the literature)

\begin{tabular}{llc}
\hline Lichen & Main constituents & Reference \\
\hline P. sulcata & $\begin{array}{l}\text { Salazinic acid, protocetraric acid, atranorin, } \\
\text { chloroatranorin }\end{array}$ & {$[16]$} \\
F. caperata & $\begin{array}{l}\text { Salazinic acid, protocetraric acid, usnic acid and } \\
\text { atranorin }\end{array}$ & {$[16]$} \\
E. prunastri & $\begin{array}{l}\text { Evernic acid, usnic acid, atranorin, chloroatranorin } \\
\text { H. physodes }\end{array}$ & $\begin{array}{l}\text { Physodalic acid, physodic acid, 3-hydroxy physodic } \\
\text { acid, atranorin }\end{array}$ \\
\hline
\end{tabular}


An additional AHC analysis (different microbial strains were used as observations; resulting dendrogram is depicted in Figure 2) showed that, based on the similarities/ dissimilarities in their susceptibility toward studied lichen extract, the tested microbial strains could also be divided into two groups. The first one was comprised of several Gramnegative bacteria ( $P$. vulgaris and $K$. pneumoniae) and fungi/yeast (A. niger and $C$. albicans), whereas the second group included all here assayed Gram-positive bacteria and three Gram-negative species (E. coli, S. enteritidis and P. aeruginosa).

\section{CONCLUSION}

The herein studied extracts showed moderate antimicrobial activity against the tested microbial strains (13 in total). Hypogymnia physodes and E. prunastri extracts (previous studies showed that these are of comparable chemical composition) had similar antimicrobial properties. The same is true for $F$. caperata and P. sulcata extracts. The tested microorganisms were not equally susceptible to the presence of different lichen extracts in their growth media.

\section{REFERENCES}

1. E. Stocker-Wörgötter, Metabolic diversity of lichen-forming ascomycetous fungi: culturing, polyketide and shikimate metabolite production, and PKS genes, Natural Product Reports, 25 (1), 188-200 (2008).

2. K. Müller, Pharmaceutically relevant metabolites from lichens, Applied Microbiology and Biotechnology, 57, 9-16 (2001).

3. G. Stojanović, I. Stojanović and A. Šmelcerović, Lichen depsidones as potential novel pharmacologically active compounds, Mini-Reviews in Organic Chemistry, 9, 178-184 (2012).

4. K. Molnar and E. Farkas, Current results on biological activities of lichen secondary metabolites: a review. Zeitschrift fur Naturforschung C: Journal of Biosciences, 65c, 157-173 (2010).

5. J. Boustie and M. Grube, Lichens, a promising source of bioactive secondary metabolites. Plant Genetic Resources, 3, 273-287 (2005).

6. B.C. Behera, N. Verma, A. Sonone and U. Makhija, Antioxidant and antibacterial properties of some cultured lichens, Bioresource Technology, 99, 776-784 (2008).

7. P.R. Burkholder, A.W. Evans, I. McVeigh and H.K. Thornton, Antibiotic activity of lichens, Proceedings of the National Academy of Sciences of the United States, 30, 250-255 (1944).

8. T.Y. Tolpysheva, Effects of lichen extracts of fungi II. Effects of joint preparation obtained from Cladina stellaris and $C$. rangiferins on growing soil fungi, Journal of Mycology and Phytopatology, 18, 384-388 (1984).

9. P. Halama and C. van Haluwin, Antifungal activity of lichen extracts and lichenic acids, Bio Control, 49, 95-107 (2004).

10. A.O. Turk, M. Yilmaz, M. Kivanc and H. Turk, The Antimicrobial activity of extracts of the lichen Cetraria aculeate and its protolichesterinic acid constituent, Zeitschrift fur Naturforschung C: Journal of Biosciences, 58, 850-854 (2003).

11. M. Yilmaz, T. Tay, M. Kivanc, H. Turk and A.O. Turk, The antimicrobial activity of extracts of the lichen Hypogymnia tubulosa and its 3-hydroxyphysodic acid constituent, Zeitschrift fur Naturforschung C: Journal of Biosciences, 60, 35-38 (2005).

12. B. Ranković, M. Mišić and S. Sukdolak. Antimicrobial activity of the lichens Caledonia furcata, Parmelia caperata, Parmelia pertusa, Hypogymnia physodes and Umbilicaria polyphylla, British Journal of Biomedical Science, 64, 143-148 (2007).

13. B. Ranković, M. Mišić and S. Sukdolak, Evaluation of antimicrobial activity of the lichens Lasallia pustulata, Parmelia sulcata, Umbilicaria crustulosa, and Umbilicaria cylindrica, Microbiology, 76, 723-727 (2007). 
14. B. Ranković, M. Mišić and S. Sukdolak, The antimicrobial activity of substances derived from the lichens Physcia aipolia, Umbilicaria polyphylla, Parmelia caperata and Hypogymnia physodes, World Journal of Microbiology and Biotechnology, 24, 1239-1242 (2008).

15. T. Mitrović, S. Stamenković, V. Cvetković, S. Tošić, M. Stanković, I. Radojević, O. Stefanović, L. Comić, D. Dačić, M. Curčić and S. Marković, Antioxidant, antimicrobial and antiproliferative activities of five lichen species, International Journal of Molecular Sciences, 12, 5428-5448 (2011).

16. N. Manojlović, B. Ranković, M. Kosanić, P. Vasiljević and T. Stanojković, Chemical composition of three Parmelia lichens and antioxidant, antimicrobial and cytotoxic activities of some their major metabolites, Phytomedicine, 19 (13), 1166-1172 (2012).

17. M. Kosanić, N. Manojlović, S. Janković, T. Stanojković and B. Ranković, Evernia prunastri and Pseudoevernia furfuraceae lichens and their major metabolites as antioxidant, antimicrobial and anticancer agents, Food and Chemical Toxicology 53, 112-118 (2013).

18. M. Kosanić, B. Ranković, and T. Stanojković, Antioxidant, antimicrobial and anticancer activities of three Parmelia species, Journal of the Science of Food and Agriculture 92, 1909-191 (2012).

19. I. Stojanović, M. Stanković, O. Jovanović, G. Petrović, A. Šmelcerović and G. Stojanović, Effect of Hypogymnia physodes extracts and their depsidones on micronucleus distribution in human lymphocytes, Natural Product Communications, 8 (1), 109-112 (2013).

20. F.H. Kayser, K.A. Bienz, J. Eckert, R.M. Zinkernagel, Medicinal Microbilogy, Thieme, Stuttgart, 2004.

21. http://en.wikipedia.org

22. M. Murati, Flora lišajeva Slovenije, Hrvatske, Vojvodine, Bosne i Hercegovine, Srbije, Crne Gore, Kosova i Makedonije 1. Viša pedagoška škola "Bajram Curri"'- Đakovica, Univerzitet u Prištini, Prizren, 1992.

23. NCCLS (National Committee for Clinical Laboratory Standards). Performance Standards for Antimicrobial Disk Susceptibility Test, $6^{\text {th }}$ ed. Approved Standard; M2-A6, 1997.

24. L. Faleiro, G. Miguel, S. Gomes, L. Costa, F. Venâncio, A. Teixeira, A.C. Figueiredo, J.G. Barroso, L.G. Pedro, Antibacterial and antioxidant activities of essential oils isolated from Thymbra capitata L. (Cav.) and Origanum vulgare L. Journal of Agricultural and Food Chemistry 53, 8162-8168 (2005).

\section{ANTIMIKROBNA AKTIVNOST METANOLNIH EKSTRAKATA ČETIRI VRSTE LIŠAJEVA IZ PORODICE PARMELIACEAE}

U ovom radu je disk-difuzionom metodom (1 mg uzorka ekstrakta po disku; ekstrakti su rastvarani u metanolu; koncentracija je bila $25 \mathrm{mg} / \mathrm{mL}$ ) određena antimikrobna aktivnost metanolnih ekstrakata četiri vrste lišaja iz porodice Parmeliaceae (Hypogymnia physodes (L.) Nyl., Evernia prunastri (L.) Ach., Flavoparmelia caperata (L.) Hale $i$ Parmelia sulcata Taylor). Testirana je aktivnost na 11 sojeva Gram-pozitivnih (Enterococus sp., Bacillus subtillis, Sarcina lutea, Micrococus luteus, Staphylococcus aureus, Clostridium sporogenes) i Gram-negativnih bakterija (Escherichia coli, Proteus vulgaris, Salmonela enteritidis, Pseudomonas aeruginosa, Klebsiella pneumoniae), i po jedna plesan (A. niger) i kvasac (C. albicans). Svi testirani ekstrakti su pokazali umerenu antimikrobnu aktivnost. Multivarijantna statistička analiza (aglomerativna hijerarhijska klaster analiza) dobijenih rezultata omogućila je da se testirani uzorci grupišu na osnovu sličnosti/razlika u pokazanoj antimikrobnoj aktivnosti prema različitim sojevima mikroorganizama: antimikrobni profili ekstrakata H. physodes $i$ E. prunastri su bili uporedivi; slično važi za ekstrakte $F$. caperata $i$ P. sulcata. Pored toga, na osnovu sličnosti/razlika $u$ osetljivosti na dejstvo ekstrakata proučavanih lišajeva, ovde testirani mikroorganizmi se mogu podeliti u dve grupe: Grupa I-P. vulgaris, K. pneumoniae (Gram-negativne bakterije), A. niger $i$ C. albicans; Grupa II - E. coli, S. enteritidis, P. aeruginosa (Gram-negativne bakterije) i sve ispitivane Gram-pozitivne vrste.

Ključne reči: Hypogymnia physodes (L.) Nyl., Evernia prunastri (L.) Ach., Flavoparmelia caperata (L.) Hale, Parmelia sulcata Taylor, metanolni ekstrakt, antimikrobna aktivnost 